\title{
Cole-Carpenter Syndrome
}

National Cancer Institute

\section{Source}

National Cancer Institute. Cole-Carpenter Syndrome. NCI Thesaurus. Code C130985.

Bone dysplasia due to autosomal dominant mutation(s) in the P4HB gene, encoding prolyl 4-hydroxylase subunit beta, or autosomal recessive mutation(s) in the SEC24D gene, encoding SEC24 homolog D, COPII coat complex component. This condition is characterized by bone fragility, growth failure, craniosynostosis, hydrocephalus, and distinctive facial features, including marked frontal bossing, blue sclerae, ocular proptosis, midface hypoplasia, and micrognathia. 